\title{
Synergistic anticancer activity of curcumin and bleomycin: An in vitro study using human malignant testicular germ cells
}

\author{
AYSEGUL CORT, MUJGAN TIMUR, EVRIM OZDEMIR, ERTAN KUCUKSAYAN and TOMRIS OZBEN \\ Department of Biochemistry, Faculty of Medicine, Akdeniz University, Antalya 07070, Turkey
}

Received December 21, 2011; Accepted March 21, 2012

DOI: $10.3892 / \mathrm{mmr} .2012 .848$

\begin{abstract}
Testicular cancer is the most common cancer among young men of reproductive age. Bleomycin is a frequently used drug for the treatment of several malignancies and is part of the chemotherapy protocols used for testicular cancer; however, side-effects are common. Bleomycin causes an increase in oxidative stress which has been shown to induce apoptosis in cancer cells. Curcumin (diferuloylmethane), an active component of the spice turmeric, has been demonstrated to induce apoptosis in a number of malignancies. However, to date no study has been carried out to elucidate its anticancer activity and interaction with bleomycin in testicular cancer cells. In this study, we investigated and compared the effects of curcumin, bleomycin and hydrogen peroxide $\left(\mathrm{H}_{2} \mathrm{O}_{2}\right)$ on apoptotic signaling pathways Curcumin $(20 \mu \mathrm{M})$, bleomycin $(400 \mu \mathrm{g} / \mathrm{ml})$ and $\mathrm{H}_{2} \mathrm{O}_{2}(400 \mu \mathrm{M})$ incubation for $24 \mathrm{~h}$ decreased the viability of NTera- 2 cells, and increased caspase- $3,-8$ and -9 activities, Bax and cytoplasmic cytochrome c levels and decreased Bcl-2 levels. The concurrent use of curcumin with bleomycin induced caspase-3, -8 and -9 activities to a greater extent in NTera- 2 cells than the use of each drug alone. Our observations suggest that the effects of curcumin and bleomycin on apoptotic signaling pathways are synergistic. Therefore, we propose to use curcumin together with bleomycin to decrease its therapeutic dose and, therefore, its side-effects.
\end{abstract}

\section{Introduction}

Testicular germ cell tumors represent the most common solid malignancy of young men aged 15-40 years. Molecular studies have presented strong evidence of an association between genetic alterations and testicular germ cell tumors (1). Numerous in vitro studies have demonstrated that a wide range of anticancer agents induce apoptosis in malignant cells by generating reactive oxygen species (ROS). Bleomycin, a widely

Correspondence to: Professor Tomris Ozben, Department of Biochemistry, Faculty of Medicine, Akdeniz University, Dumlupinar Blv., Antalya 07070, Turkey

E-mail: ozben@akdeniz.edu.tr

Key words: apoptosis, bleomycin, curcumin, testicular cancer used antitumor agent in the treatment of testicular cancer, is well-known for causing single- and double-strand breaks in cellular DNA in vivo and in vitro, eventually leading to the genomic instability of damaged cells. Bleomycin causes an increase in ROS resulting in oxidative stress which induces apoptosis. Free radical generation and subsequent oxidative stress also mediate the toxic effects of bleomycin via inducing apoptosis. In this study, we compared the effects of bleomycin on apoptotic signaling pathways, by measuring caspase-3, -8 and -9 activities, Bax, cytoplasmic cytochrome c (Cyt-c) and Bcl-2 levels with hydrogen peroxide $\left(\mathrm{H}_{2} \mathrm{O}_{2}\right)$ which directly produces ROS. $\mathrm{H}_{2} \mathrm{O}_{2}$ alters the intracellular redox state, as well as mitochondrial membrane potential and releases $\mathrm{Cyt}-\mathrm{c}$ from the mitochondria into the cytosol. $\mathrm{H}_{2} \mathrm{O}_{2}$ induces apoptosis by causing the release of Cyt-c from the mitochondria and apoptosis-inducing factor, through the opening of a non-selective mitochondrial permeability transition pore. Moreover, $\mathrm{H}_{2} \mathrm{O}_{2}$ has been found to trigger the activation of multiple signaling pathways, thereby modulating the expression of a great number of genes (2).

Curcumin (diferuloylmethane) is the chief component of the spice, turmeric, and is isolated from Curcuma longa. Curcumin is responsible for the yellow color of the spice as well as the majority of turmeric's therapeutic effects (3). Curcumin has been demonstrated to have anticancer activities both in vitro in many cancer cell lines and in vivo models. Curcumin has been shown to suppress cell proliferation, inflammation, induce apoptosis, sensitize tumor cells to cancer therapies and suppress the invasion, angiogenesis and metastasis of cancer cells $(4,5)$. Curcumin plays a key role in the modulation of several important molecular targets, including transcription factors, anti-apoptotic proteins, enzymes, cytokines and chemokines $(6,7)$. Curcumin has been demonstrated to have a stimulatory effect on the extrinsic and intrinsic apoptotic pathways $(8,9)$. Curcumin has been shown to selectively induce apoptosis in tumor cells at the $\mathrm{G} 2$ phase via the upregulation of p53 expression and initiation of the mitochondrial apoptotic pathway via increased Bax expression and Cyt-c release (10-12). No study has been carried out to date to elucidate the anticancer activity of curcumin and its interaction with bleomycin and $\mathrm{H}_{2} \mathrm{O}_{2}$ in the induction of apoptosis in human testicular cancer cells.

The aim of this study was to clarify the molecular mechanisms and pathways of apoptosis which may be induced by $\mathrm{H}_{2} \mathrm{O}_{2}$, bleomycin and curcumin in the NTera-2 (NT2) human wild-type p53-expressing testicular cancer cell line. We deter- 
mined the cytotoxic effect of $\mathrm{H}_{2} \mathrm{O}_{2}$, bleomycin and curcumin on NT2 cells and measured apoptotic signaling pathway markers, such as caspase-3, -8 and -9 activities, and Bcl-2, Bax and Cyt-c levels in NT2 cells incubated with $\mathrm{H}_{2} \mathrm{O}_{2}$ or bleomycin in the presence or absence of curcumin $\left(\mathrm{H}_{2} \mathrm{O}_{2}+\right.$ curcumin or bleomycin + curcumin).

\section{Materials and methods}

Cell line. NT2 cells were obtained from the American Type Culture Collection. Cell identity was not authenticated by the authors. Cells were grown to confluence at $37^{\circ} \mathrm{C}$ in a humidified atmosphere containing $5 \% \mathrm{CO}_{2}$ in air in DMEM medium supplemented with $10 \%$ fetal bovine serum (Invitrogen, Carlsbad, CA, USA), $100 \mathrm{IU} / \mathrm{ml}$ penicilin and $10 \mu \mathrm{g} / \mathrm{ml}$ streptomycin (catalog\# 15140, Invitrogen ${ }^{\mathrm{TM}}$ ). No authentication of the cells other than that by the American Type Culture Collection using short tandem repeat analysis was performed on the cells used in this study. One day prior to the experiments, NT2 cells were plated in culture dishes. Cells were then incubated with $\mathrm{H}_{2} \mathrm{O}_{2}$ (Sigma, St. Louis, MO, USA) and bleomycin (Nippon Kayaku, Tokyo, Japan) and/or curcumin (Sigma) for $24 \mathrm{~h}$.

Viability assay. The viability of the cells was measured using the colorimetric 3-(4,5) dimethylthiazol-2-yl)-2,5-diphenyltetrazolium bromide (MTT) assay. The principle of this method is based on cellular reduction of MTT to a blue formazan product by mitochondrial dehydrogenases of viable cells. The intensity of the blue color formed by this procedure is a criterion for cell viability. Cell viability was determined by seeding $5 \times 10^{4}$ cells/well in 96-well plates, and incubating them for 1 day in DMEM with 10\% FBS. The following day, the cells were incubated with different concentrations of $\mathrm{H}_{2} \mathrm{O}_{2}(50-500 \mu \mathrm{M})$, bleomycin (100-600 $\left.\mu \mathrm{g} / \mathrm{ml}\right)$ and different concentrations of curcumin $(5-25 \mu \mathrm{M})$ for $24 \mathrm{~h}$. Control cells were prepared in plates containing only medium. Following incubation, MTT (Millipore Billerica, MA, USA) was added into each well and incubated for $4 \mathrm{~h}$. Isopropanol $(0.1 \mathrm{ml})$ containing $0.04 \mathrm{~N} \mathrm{HCl}$ was added into each well and a microplate reader (BioTek, Winooski, VT, USA) was used to measure the absorbances at $570 \mathrm{~nm}$. The average absorbance values of the cells were compared to those of the control cells to calculate the percentage of the viable cells.

Caspase-3 assay. This assay was performed using a commercial kit (ApoTarget kit, code: KHZ0022; BioSource International, Inc., Camarillo, CA, USA). The colorimetric protease assay of caspase- 3 provides a simple and convenient means of quantifying the enzyme activity that recognizes the amino acid sequence, DEVD [a synthetic tetrapeptide, (Asp-GlueVal-Asp), which is the upstream amino acid sequence of the caspase-3 cleavage site], coupled with p-nitroanilide, which is released upon substrate cleavage. Cells $\left(2 \times 10^{6}\right)$ were incubated with $\mathrm{H}_{2} \mathrm{O}_{2}$, bleomycin, curcumin or $\mathrm{H}_{2} \mathrm{O}_{2}+$ curcumin, bleomycin + curcumin for $24 \mathrm{~h}$, while untreated cells acted as the control. The cells were lysed by the addition of $50 \mu 1$ of chilled cell lysis buffer and incubated on ice for $10 \mathrm{~min}$. The resulting cell lysate was centrifuged for $1 \mathrm{~min}$ at $10,000 \mathrm{x} \mathrm{g}$, and the supernatant was collected. Fifty microliters of $2 \mathrm{X}$ reaction buffer (containing $10 \mathrm{mM}$ DTT) were added to each sample.
Then, $5 \mu 1$ of DEVD-pNA (caspase-3 substrate) were added and incubated in the dark at $37^{\circ} \mathrm{C}$ for $1 \mathrm{~h}$. At the end of the incubation period, the absorbances of the samples were read at $405 \mathrm{~nm}$ in a microplate reader (BioTek). Data are presented as the means $\pm \mathrm{SE}$.

Caspase-8 assay. This assay was performed using a commercial kit (ApoTarget kit, code: KHZ0061; BioSource International, Inc.).

Caspase- 9 assay. This assay was performed using a commercial kit (ApoTarget kit, code: KHZ0101; BioSource International, Inc.).

Bax assay. Bax protein concentration determination was carried out using the Human Bax Enzyme Immunometric Assay kit (Assay Designs, Ann Arbor, MI, USA). The lysate (sample) preparation was carried out according to the manual. Following centrifugation (16,000 x g for $15 \mathrm{~min})$, the cells were resuspended in Modified Cell Lysis Buffer 4 [0.5 $\mu \mathrm{l} /$ $\mathrm{ml}$ of Sigma Protease Inhibitor Cocktail and $1 \mathrm{mM}$ phenylmethylsulfonyl fluoride (PMSF)]. Cell lysate (100 $\mu \mathrm{l})$ (sample) was added into the wells coated with monoclonal antibody to human Bax- $\alpha$ in triplicate. The plate was tapped gently to mix the contents. The sample was incubated at room temperature on a plate shaker for $1 \mathrm{~h}$. The wells were emptied and washed with $5 \mathrm{X}$ wash buffer. After the final wash, the plate was tapped gently on a lint free paper towel to remove any remaining wash buffer. The sample was incubated again for $1 \mathrm{~h}$ at room temperature on a plate shaker after the addition of $100 \mu 1$ of yellow antibody (biotinylated monoclonal antibody to Bax- $\alpha$ ) into each well. The wells were washed again with $5 \mathrm{X}$ wash buffer and emptied. Next, $100 \mu$ l of blue conjugate (streptavidin conjugated to horseradish peroxidase) was added into each well. The sample was left on a plate shaker for $30 \mathrm{~min}$ at room temperature. The wells were washed again as in the previous step. Solution $(100 \mu \mathrm{l})$ of 3.3',5.5' tetramethylbenzidine (TMB) and $\mathrm{H}_{2} \mathrm{O}_{2}$ was added into each well. Finally, $100 \mu \mathrm{l}$ of stop solution containing hydrochloric acid in water was added to stop the enzyme reaction. The optical densities were read at 450 and $570 \mathrm{~nm}$ using an ELISA reader. Bax protein concentration was determined from the standard protein graphic using the optical densities of the samples.

Bcl-2 assay. The intracellular content of Bcl-2 was quantified using the human Bcl-2 ELISA kit (Bender Medsystems). For the sample preparation, the cells were lysed with $1 \mathrm{X}$ lysis buffer. After $1 \mathrm{~h}$ of incubation at room temperature, the sample was spun at $1,000 \mathrm{x} g$ for $15 \mathrm{~min}$ and the supernatant was used for Bcl-2 measurement. Briefly, $80 \mu \mathrm{l}$ of sample diluent and $20 \mu \mathrm{l}$ of sample were added into the wells coated with monoclonal antibody to human Bcl-2, and after that the wells were washed twice with the wash buffer. Next, $50 \mu l$ of biotin-conjugate were added into the wells. After $2 \mathrm{~h}$ of incubation at room temperature on a microplate shaker, $100 \mu \mathrm{l}$ of streptavidinhorseradish peroxidase were added. The sample was incubated again for $1 \mathrm{~h}$ at room temperature on a microplate shaker. The solution was withdrawn and the wells were washed with $3 \mathrm{X}$ wash buffer. Immediately, $100 \mu 1$ of TMB substrate solution were added. Finally, $100 \mu \mathrm{l}$ of stop solution were added into 
each well to stop the enzyme reaction. The absorbance was read using an ELISA reader at 450- and 620-nm wavelengths. $\mathrm{Bcl}-2$ protein concentration was determined from the standard protein graphic using the optical densities of the samples.

Cytosolic Cyt-c assay. The Cytochrome c Release Apoptosis Assay kit (Calbiochem) was used to obtain cytosolic cytochrome fraction. Cells were collected by centrifugation at $600 \mathrm{x}$ g for $5 \mathrm{~min}$ at $4^{\circ} \mathrm{C}$. The cell pellets were washed once with ice-cold PBS and resuspended in Cytosol Extraction Buffer (20 mM Hepes-KOH, pH 7.5, $10 \mathrm{mM} \mathrm{KCl,} 1.5 \mathrm{mM} \mathrm{MgCl}$, $1 \mathrm{mM}$ sodium EDTA, $1 \mathrm{mM}$ sodium EGTA, $1 \mathrm{mM}$ dithiothreitol and $0.1 \mathrm{mM}$ PMSF) containing $250 \mathrm{mM}$ sucrose on ice for $10 \mathrm{~min}$. The cells were homogenized with the grinder on ice. Passes (30-50) were performed and the homogenates were centrifuged at $700 \mathrm{x}$ g for $10 \mathrm{~min}$ at $4^{\circ} \mathrm{C}$. The supernatants were centrifuged at $10,000 \mathrm{x}$ g for $30 \mathrm{~min}$ at $4^{\circ} \mathrm{C}$. Supernatant was collected as cytosolic fraction.

Cyt-c assay. Cytosolic Cyt-c levels were determined using the Cyt-c ELISA kit (Calbiochem). Sample or standard (100 $\mu \mathrm{l})$ was added into each well and incubated for $2 \mathrm{~h}$ at room temperature. The wells were washed four times with wash buffer. The plate was inverted and cleaned with paper toweling. Cyt-c conjugate $(200 \mu \mathrm{l})$ was added into each well and incubated for $2 \mathrm{~h}$ at room temperature. Wells were washed four times with wash buffer. Substrate solution $(200 \mu \mathrm{l})$ was added into each well and incubated for $30 \mathrm{~min}$ at room temperature. Finally, $50 \mu \mathrm{l}$ of stop solution were added into each well. The optical density of each well was determined using a plate reader at a 450-nm wavelength.

Statistical analysis. All the data are presented as the average \pm standard error (mean $\pm \mathrm{SE}$ ). Statistical analysis was performed using SPSS Data Access Pack for Windows version 10.0 (SPSS Inc., Chicago, IL, USA). p $<0.05$ was considered as a significant difference. Comparison of the non-parametric data among the groups was performed using the Mann-Whitney U test.

\section{Results}

Half maximal inhibitory concentration $\left(\mathrm{IC}_{50}\right)$ of $\mathrm{H}_{2} \mathrm{O}_{2}$, bleomycin and curcumin on NT2 cell viability. We incubated NT2 cells with different concentrations of $\mathrm{H}_{2} \mathrm{O}_{2}(50-500 \mu \mathrm{M})$, bleomycin $(100-600 \mu \mathrm{g} / \mathrm{ml})$ and curcumin $(5-25 \mu \mathrm{M})$ for $24 \mathrm{~h}$ and measured cell viability using the MTT assay. The cell viability of NT2 cells (control) incubated with no agent was arbitrarily set as $100 \%$ and the cell viability of the other groups was compared to the viability of the control cells. According to the results of these experiments, we found the $\mathrm{IC}_{50}$ of $\mathrm{H}_{2} \mathrm{O}_{2}$ on NT2 cell viability as $400 \mu \mathrm{M}$ after an incubation of $24 \mathrm{~h}$ (Fig. 1A), of bleomycin as $400 \mu \mathrm{g} / \mathrm{ml}$ (Fig. 1B) and of curcumin as $20 \mu \mathrm{M}$ (Fig. 1C). We used these $\mathrm{IC}_{50}$ concentrations of $\mathrm{H}_{2} \mathrm{O}_{2}$ (400 $\mu \mathrm{M})$, bleomycin $(400 \mu \mathrm{g} / \mathrm{ml})$ and curcumin $(20 \mu \mathrm{M})$ in the incubations.

Caspase-3 activity. NT2 cells were incubated with $\mathrm{H}_{2} \mathrm{O}_{2}$, bleomycin, curcumin, $\mathrm{H}_{2} \mathrm{O}_{2}+$ curcumin or bleomycin + curcumin for $24 \mathrm{~h}$, and caspase- 3 activity was determined using the caspase-3 assay kit. The absorbances of the cell samples incu-
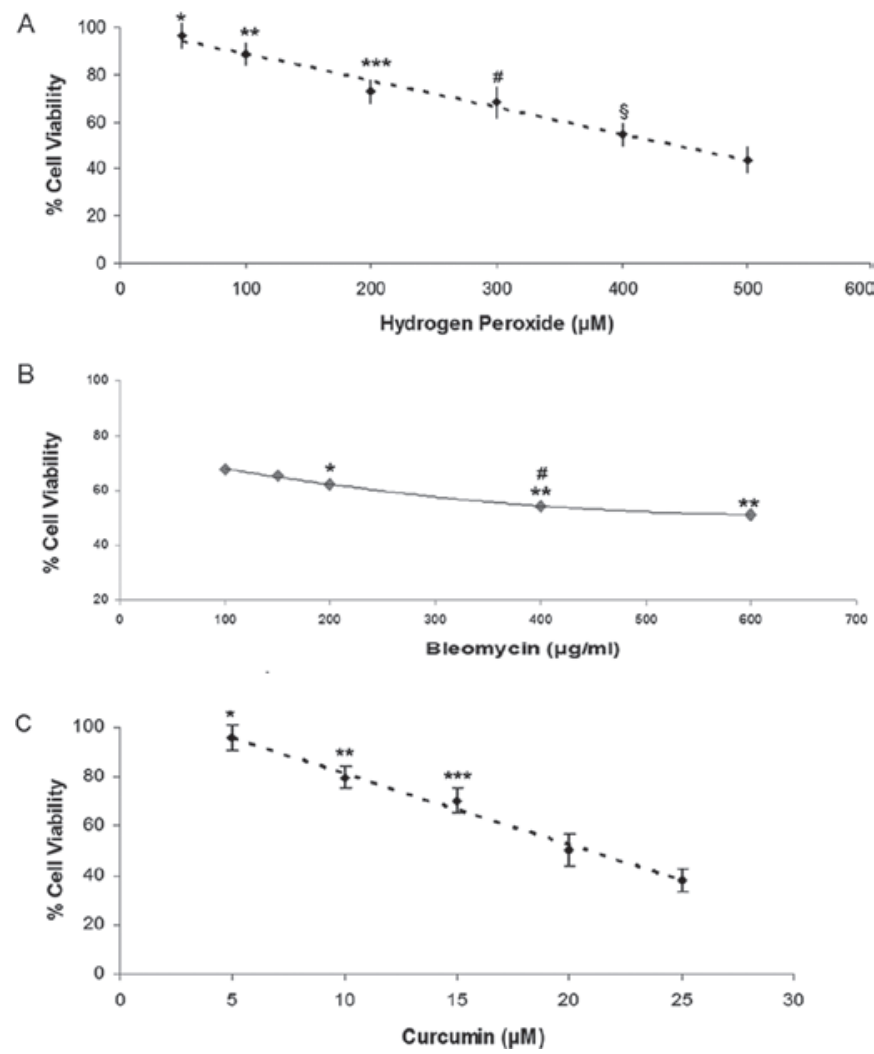

Figure 1. $\mathrm{IC}_{50}$ concentrations of $\mathrm{H}_{2} \mathrm{O}_{2}$, bleomycin and curcumin. (A) $\mathrm{IC}_{50}$ concentration of $\mathrm{H}_{2} \mathrm{O}_{2}$ on NT2 cell viability. Each value represents the mean $\pm \mathrm{SE}$ (n=6). ${ }^{*} \mathrm{p}<0.05,50 \mu \mathrm{M}$ vs. $100,200,300,400$ and $500 \mu \mathrm{M} .{ }^{* *} \mathrm{p}<0.05,100 \mu \mathrm{M}$ vs. $200,300,400$ and $500 \mu \mathrm{M} .{ }^{* * *} \mathrm{p}<0.05,200 \mu \mathrm{M}$ vs. 400 and $500 \mu \mathrm{M}$. ${ }^{\#} \mathrm{p}<0.05,300 \mu \mathrm{M}$ vs. 400 and $500 \mu \mathrm{M} .{ }^{\S} \mathrm{p}<0.05,400$ vs. $500 \mu \mathrm{M}$. (B) $\mathrm{IC}_{50}$ concentration of bleomycin on NT2 cell viability. Each value represents the mean $\pm \mathrm{SE}(\mathrm{n}=6) .{ }^{*} \mathrm{p}<0.05,200 \mu \mathrm{g} / \mathrm{ml}$ vs. 100 and $150 \mu \mathrm{g} / \mathrm{ml} .{ }^{* *} \mathrm{p}<0.05,400$ and $600 \mu \mathrm{g} / \mathrm{ml}$ vs. 100,150 and $200 \mu \mathrm{g} / \mathrm{ml} .{ }^{\#} \mathrm{p}<0.05,400 \mathrm{vs} .600 \mu \mathrm{g} / \mathrm{ml}$. (C) $\mathrm{IC}_{50}$ concentration of curcumin on NT2 cell viability. Each value represents the mean $\pm \mathrm{SE}(\mathrm{n}=6) .{ }^{*} \mathrm{p}<0.05,5 \mu \mathrm{M}$ vs. $10,15,20$ and $25 \mu \mathrm{M} .{ }^{* *} \mathrm{p}<0.05$ $10 \mu \mathrm{M}$ vs. 20 and $25 \mu \mathrm{M} .{ }^{* * *} \mathrm{p}<0.0515 \mu \mathrm{M}$ vs. 20 and $25 \mu \mathrm{M}$.

bated with different agents were compared to the absorbance of the control cells not incubated with any agent to determine the change in caspase- 3 activity. The caspase- 3 activity in the NT2 cells is shown in Fig. 2A. Incubation with curcumin, bleomycin, bleomycin + curcumin, $\mathrm{H}_{2} \mathrm{O}_{2}$ and $\mathrm{H}_{2} \mathrm{O}_{2}+$ curcumin induced a significant increase in caspase- 3 activity compared to the control group. The highest increase in caspase- 3 activity was found in the cells incubated with bleomycin + curcumin compared to the other groups.

Caspase-8 activity. NT2 cells were incubated with $\mathrm{H}_{2} \mathrm{O}_{2}$, bleomycin, curcumin, $\mathrm{H}_{2} \mathrm{O}_{2}+$ curcumin or bleomycin + curcumin for $24 \mathrm{~h}$, and caspase- 8 activity was determined using the caspase- 8 assay kit. The absorbances of the cell samples incubated with different agents were compared to the absorbance of the control cells not incubated with any agent to determine the change in caspase- 8 activity. The caspase- 8 activity in the NT2 cells incubated with different agents for $24 \mathrm{~h}$ is shown in Fig. 2B. Incubation with curcumin, bleomycin, bleomycin + curcumin, $\mathrm{H}_{2} \mathrm{O}_{2}$ and $\mathrm{H}_{2} \mathrm{O}_{2}+$ curcumin induced a marked increase in caspase- 8 activity compared to the control group. Co-incubation with bleomycin + curcumin significantly increased caspase- 8 activity compared to the other groups. 

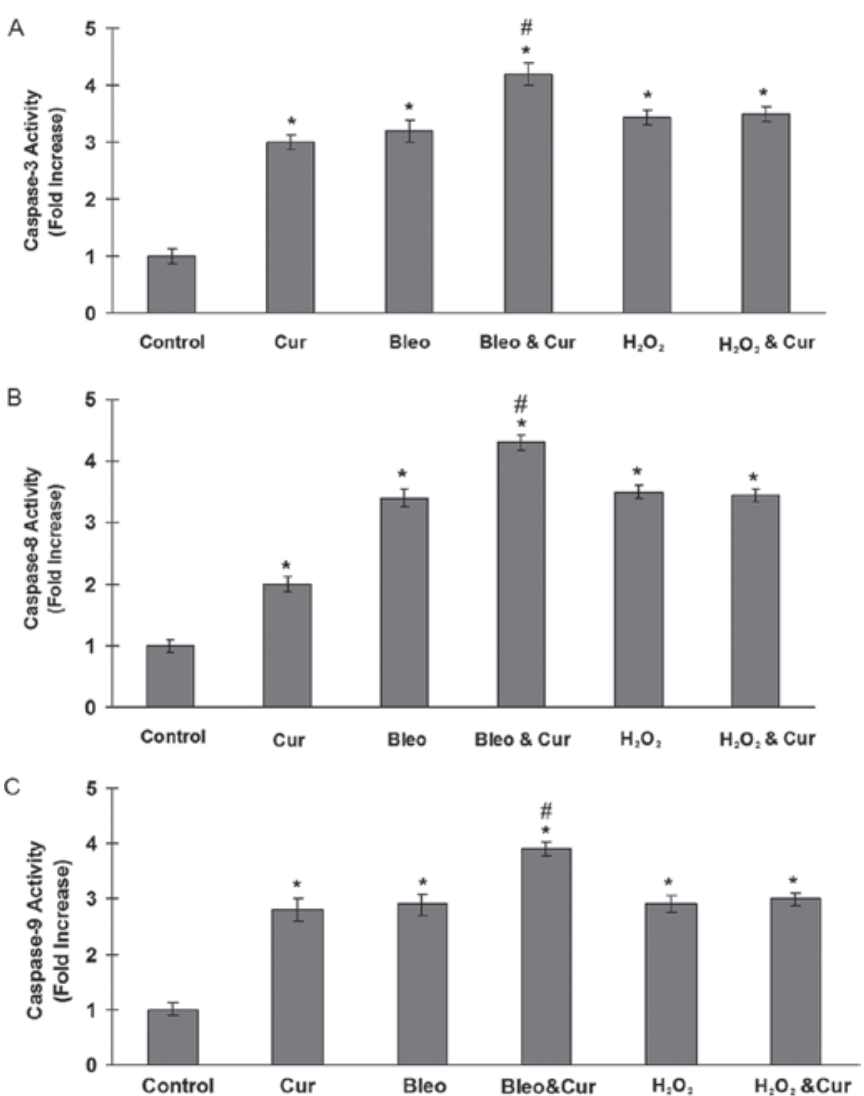

Figure 2. Caspase activities. (A) Caspase-3 activity in NT2 cells incubated with curcumin, bleomycin, bleomycin + curcumin, $\mathrm{H}_{2} \mathrm{O}_{2}$ and $\mathrm{H}_{2} \mathrm{O}_{2}+$ curcumin for $24 \mathrm{~h}$. Each value represents the mean $\pm \mathrm{SE}(\mathrm{n}=6)$. ${ }^{*} \mathrm{p}<0.05$, curcumin, bleomycin, bleomycin + curcumin, $\mathrm{H}_{2} \mathrm{O}_{2}$ and $\mathrm{H}_{2} \mathrm{O}_{2}+$ curcumin vs. control. ${ }^{\#} \mathrm{p}<0.05$, bleomycin + curcumin vs. curcumin, bleomycin, $\mathrm{H}_{2} \mathrm{O}_{2}$ and $\mathrm{H}_{2} \mathrm{O}_{2}+$ curcumin. (B) Caspase- 8 activity in NT2 cells incubated with curcumin, bleomycin, bleomycin + curcumin, $\mathrm{H}_{2} \mathrm{O}_{2}$ and $\mathrm{H}_{2} \mathrm{O}_{2}+$ curcumin for $24 \mathrm{~h}$. Each value represents the mean $\pm \mathrm{SE}(\mathrm{n}=6)$. ${ }^{*} \mathrm{p}<0.05$, curcumin, bleomycin, bleomycin + curcumin, $\mathrm{H}_{2} \mathrm{O}_{2}$ and $\mathrm{H}_{2} \mathrm{O}_{2}+$ curcumin vs. control. ${ }^{*} \mathrm{p}<0.05$, bleomycin + curcumin vs. curcumin, bleomycin, $\mathrm{H}_{2} \mathrm{O}_{2}$ and $\mathrm{H}_{2} \mathrm{O}_{2}+$ curcumin. (C) Caspase- 9 activity in NT2 cells incubated with curcumin, bleomycin, bleomycin + curcumin, $\mathrm{H}_{2} \mathrm{O}_{2}$ and $\mathrm{H}_{2} \mathrm{O}_{2}+$ curcumin for $24 \mathrm{~h}$. Each value represents the mean $\pm \mathrm{SE}(\mathrm{n}=6) .{ }^{*} \mathrm{p}<0.05$, curcumin, bleomycin, bleomycin + curcumin, $\mathrm{H}_{2} \mathrm{O}_{2}$ and $\mathrm{H}_{2} \mathrm{O}_{2}+$ curcumin vs. control. " $\mathrm{p}<0.05$, bleomycin + curcumin vs. curcumin, bleomycin, $\mathrm{H}_{2} \mathrm{O}_{2}$ and $\mathrm{H}_{2} \mathrm{O}_{2}+$ curcumin. Cur, curcumin; Bleo, bleomycin.

Caspase- 9 activity. NT2 cells were incubated with $\mathrm{H}_{2} \mathrm{O}_{2}$, bleomycin, curcumin, $\mathrm{H}_{2} \mathrm{O}_{2}+$ curcumin or bleomycin + curcumin for $24 \mathrm{~h}$, and caspase- 9 activity was determined using the caspase-9 assay kit. The absorbances of the cell samples incubated with different agents were compared to the absorbance of the control cells not incubated with any agent to determine the change in caspase- 9 activity. The caspase- 9 activity in the NT2 cells incubated with different agents for $24 \mathrm{~h}$ is shown in Fig. 2C. Caspase-9 activity was significantly increased in the NT2 cells induced with the different agents or their combinations compared to the control group. Co-incubation with bleomycin + curcumin significantly increased caspase- 9 activity compared to the other groups.

Bax levels. NT2 cells were incubated with $\mathrm{H}_{2} \mathrm{O}_{2}$, bleomycin, curcumin, $\mathrm{H}_{2} \mathrm{O}_{2}+$ curcumin or bleomycin + curcumin for $24 \mathrm{~h}$, and Bax concentration was determined using a Bax assay kit. Bax levels in the NT2 cells incubated with the different agents

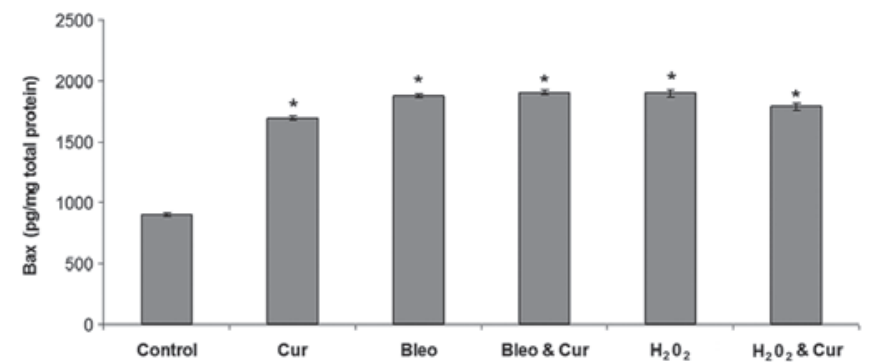

Figure 3. Bax levels. Bax levels in NT2 cells incubated with curcumin, bleomycin, bleomycin + curcumin, $\mathrm{H}_{2} \mathrm{O}_{2}$ and $\mathrm{H}_{2} \mathrm{O}_{2}+$ curcumin for $24 \mathrm{~h}$. Each value represents the mean $\pm \mathrm{SE}(\mathrm{n}=6)$. ${ }^{*} \mathrm{p}<0.05$, curcumin, bleomycin, bleomycin + curcumin, $\mathrm{H}_{2} \mathrm{O}_{2}$ and $\mathrm{H}_{2} \mathrm{O}_{2}+$ curcumin vs. control. Cur, curcumin; Bleo, bleomycin.

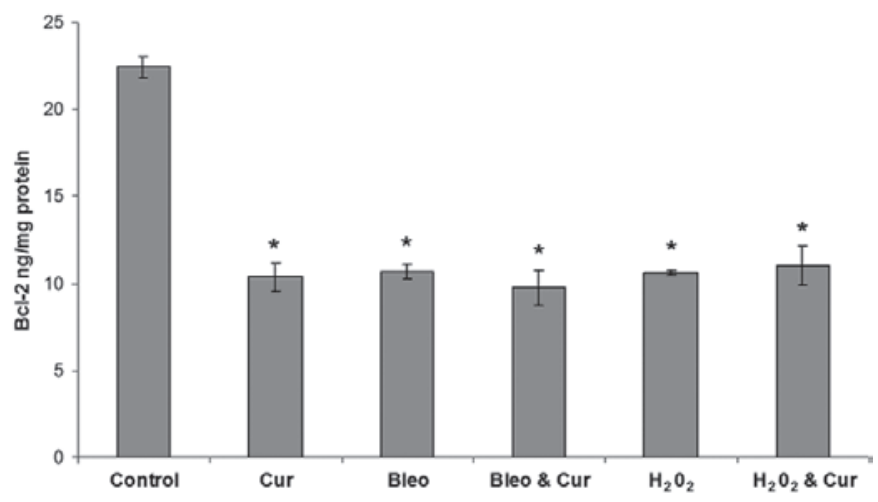

Figure 4. Bcl-2 levels. Bcl-2 levels in NT2 cells incubated with curcumin, bleomycin, bleomycin + curcumin, $\mathrm{H}_{2} \mathrm{O}_{2}$ and $\mathrm{H}_{2} \mathrm{O}_{2}+$ curcumin for $24 \mathrm{~h}$. " $\mathrm{p}<0.05$, curcumin, bleomycin, bleomycin + curcumin, $\mathrm{H}_{2} \mathrm{O}_{2}$ and $\mathrm{H}_{2} \mathrm{O}_{2}+$ curcumin vs. control. Cur, curcumin; Bleo, bleomycin.

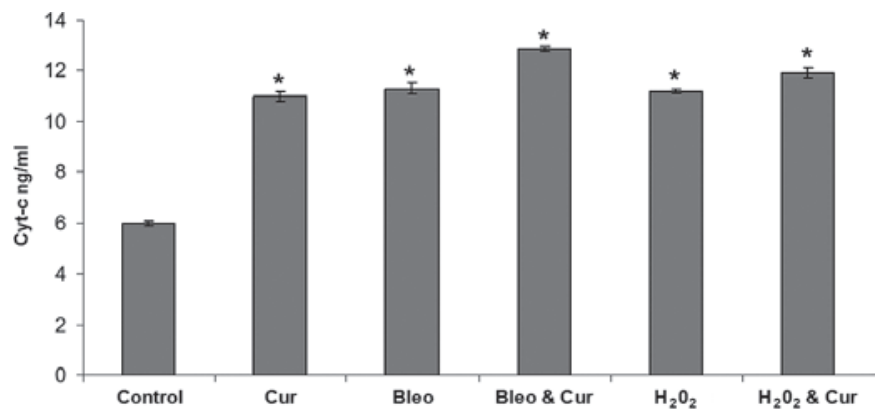

Figure 5. Cytochrome c (Cyt-c) levels. Cyt-c levels in NT2 cells incubated with curcumin, bleomycin, bleomycin + curcumin, $\mathrm{H}_{2} \mathrm{O}_{2}$ and $\mathrm{H}_{2} \mathrm{O}_{2}+$ curcumin for 24 h. ${ }^{*}$ p $<0.05$, curcumin, bleomycin, bleomycin + curcumin, $\mathrm{H}_{2} \mathrm{O}_{2}$ and $\mathrm{H}_{2} \mathrm{O}_{2}+$ curcumin vs. control. Cur, curcumin; Bleo, bleomycin.

or their combinations for $24 \mathrm{~h}$ are shown in Fig. 3. Incubation with curcumin, bleomycin, bleomycin + curcumin, $\mathrm{H}_{2} \mathrm{O}_{2}$ and $\mathrm{H}_{2} \mathrm{O}_{2}+$ curcumin increased Bax levels significantly compared to the control group. There was no significant difference in the Bax levels in the NT2 cells incubated with the different agents or their combinations.

Bcl-2 levels. NT2 cells were incubated with $\mathrm{H}_{2} \mathrm{O}_{2}$, bleomycin, curcumin, $\mathrm{H}_{2} \mathrm{O}_{2}+$ curcumin or bleomycin + curcumin for 
$24 \mathrm{~h}$, and anti-apoptotic protein Bcl-2 levels were determined using a quantitative ELISA Bcl-2 assay kit. Bcl-2 levels in the NT2 cells incubated with the different agents or their combinations for $24 \mathrm{~h}$ are shown in Fig. 4 . Bcl-2 content in NT2 cell lysates was significantly reduced after curcumin, bleomycin, bleomycin + curcumin, $\mathrm{H}_{2} \mathrm{O}_{2}$ and $\mathrm{H}_{2} \mathrm{O}_{2}+$ curcumin incubation compared to the control group. There was no significant difference in the Bcl-2 levels in the NT2 cells incubated with the different agents or their combinations.

Cyt-c levels. NT2 cells were incubated with $\mathrm{H}_{2} \mathrm{O}_{2}$, bleomycin, curcumin, $\mathrm{H}_{2} \mathrm{O}_{2}+$ curcumin or bleomycin + curcumin for $24 \mathrm{~h}$, and cytoplasmic Cyt-c levels were determined with the Cyt-c assay kit. Cyt-c levels in the NT2 cells incubated with the different agents or their combinations for $24 \mathrm{~h}$ are shown in Fig. 5. Incubation with curcumin, bleomycin, bleomycin + curcumin, $\mathrm{H}_{2} \mathrm{O}_{2}, \mathrm{H}_{2} \mathrm{O}_{2}+$ curcumin increased Cyt-c levels significantly compared to the control group. There was no significant difference in the Bcl-2 levels in the NT2 cells incubated with the different agents or their combinations.

\section{Discussion}

Curcumin exerts anticancer effects on several different forms of human cancer cells. However, the mechanism by which curcumin exerts its anticancer effects requires further research. Despite evidence of curcumin's potential as an anticancer cytotoxic agent, we have little understanding of the mechanism, which involves different effects on different cell types. The effects of curcumin are biphasic; it promotes wound healing, but also can be cytotoxic. We found that curcumin caused the cell death of NT2 cells in a dose-dependent manner. We determined its effect on apoptotic signaling pathways by measuring caspase activities, Bax, Bcl-2 and cytoplasmic Cyt-c levels. The mitochondria play a crucial role in the apoptotic process by integrating numerous apoptotic signals emanating from the extracellular environment and from the intracellular milieu and other organelles. In addition, the mitochondria coordinate caspase-dependent and -independent degradation steps of apoptosis (13). The release of Cyt-c into the cytosol is associated with apoptosis (14).

It is generally accepted that oxidative stress plays an important role in apoptosis. Intracellular ROS function as a trigger or signaling molecules to initiate downstream events in regulating the cell cycle, cell differentiation and apoptosis. The dysfunction of the mitochondria produces ROS, which alter the cell processes (15). Our results showed that curcumin promoted Cyt-c release from the mitochondria followed by the activation of caspase- 9 which, in turn, activates caspase- 3 . Our data suggest that treatment with curcumin promotes the release of Cyt-c, which activates caspase-9 and caspase-3, inducing mitochondrial apoptotic pathway. Furthermore, the curcumin treatment of NT2 cells also caused caspase- 8 activation. Caspase- 8 is usually activated via stimulation of a death receptor. Caspase- 8 is also activated in a death receptorindependent way via caspase-3 following the induction of the mitochondrial pathway of apoptosis (16). The release of Cyt-c from mitochondria into cytosol is regulated by $\mathrm{Bcl}-2$ family members via multiple molecular mechanisms. Many studies have indicated that members of the Bcl-2 family are the mediators of cell survival and apoptosis (17). Bcl-2 inhibits apoptosis by preventing Cyt-c release, while Bax promotes apoptosis by triggering Cyt-c release. In our study, curcumin treatment enhanced the expression of Bax and inhibited the expression of $\mathrm{Bcl}-2$. We found that curcumin induced caspasedependent apoptotic signaling pathways, accompanied by a decreased Bcl-2 expression and increased Bax and Cyt-c levels in NT2 cell lines. Similar to our findings, several studies have reported that curcumin decreased Bcl-2 levels in many types of cancer cells, such as squamous cell carcinoma (18), small cell lung cancer (19), myeloid leukemia (20) and adenocarcinoma cells (21). Our results are consistent with those from other reports of curcumin-mediated cytotoxic activity via the induction of apoptosis (22). Our findings provide a better mechanistic understanding of curcumin-induced apoptotic signaling pathways and provide rationale for the use of curcumin in clinical studies of testicular cancer.

In this study, $\mathrm{H}_{2} \mathrm{O}_{2}$ and bleomycin treatment decreased the viability of NT2 cells, and induced apoptotic signaling pathways as indicated by increases in caspase activities, Bax and cytoplasmic Cyt-c levels and a decrease in the anti-apoptotic Bcl-2 levels. $\mathrm{H}_{2} \mathrm{O}_{2}$-mediated apoptosis has been studied as a model for ROS-induced apoptosis in several experimental situations $(23,24)$. Bleomycin is an anticarcinogenic agent which produces ROS. When we compared the effects of bleomycin on NT2 cell apoptotic signaling pathways to $\mathrm{H}_{2} \mathrm{O}_{2}$ which directly produces ROS, we found that bleomycin and $\mathrm{H}_{2} \mathrm{O}_{2}$ induced both the mitochondrial and death receptor pathways of apoptosis. Bleomycin and $\mathrm{H}_{2} \mathrm{O}_{2}$ increased caspase-3, -8 and -9 activities, pro-apoptotic Bax and cytoplasmic Cyt-c levels and decreased anti-apoptotic Bcl-2 levels. The co-incubation of bleomycin and $\mathrm{H}_{2} \mathrm{O}_{2}$ with curcumin caused a decrease in $\mathrm{Bcl}-2$ protein levels. We demonstrated that the co-incubation of bleomycin with curcumin induced caspase-3, -8 and -9 activities more than their single uses in NT2 cells. Our findings are original and have never been reported in the literature. Bleomycin has proven to be an essential component of the cisplatin-based chemotherapy regimens, used in the treatment of testicular cancer (25). However, the use of bleomycin is limited due to bleomycin-induced pneumonitis, a complication occurring in approximately $10 \%$ of patients treated with bleomycin and fatal in approximately $10 \%$ of cases (26). The co-administration of bleomycin with curcumin could be a new strategy which would allow the use bleomycin at a lower dosage and would thus prevent patients from bleomycin-induced side-effects.

\section{Acknowledgements}

This study was supported by TUBITAK of Turkey (COSTCM0603-15).

\section{References}

1. Winter C and Albers P: Testicular germ cell tumors: pathogenesis, diagnosis and treatment. Nat Rev Endocrinol 7: 43-53, 2011.

2. Jiang B, Liu JH, Bao YM and An LJ: Hydrogen peroxide-induced apoptosis in pc1 2 cells and the protective effect of puerarin. Cell Biol Int 27: 1025-1031, 2003.

3. Duvoix A, Blasius R, Delhalle S, et al: Chemopreventive and therapeutic effects of curcumin. Cancer Lett 223: 181-190, 2005 . 
4. Aggarwal BB, Kumar A and Bharti AC: Anticancer potential of curcumin: preclinical and clinical studies. Anticancer Res 23: 363-398, 2003.

5. Lin SS, Lai KC, Hsu SC, et al: Curcumin inhibits the migration and invasion of human A549 lung cancer cells through the inhibition of matrix metalloproteinase-2 and -9 and vascular endothelial growth factor (VEGF). Cancer Lett 285: 127-133, 2009.

6. Shishodia S, Sethi G and Aggarwal BB: Curcumin: getting back to the roots. Ann NY Acad Sci 1056: 206-217, 2005.

7. Tomita M, Holman BJ, Santoro CP and Santoro TJ: Astrocyte production of the chemokine macrophage inflammatory protein-2 is inhibited by the spice principle curcumin at the level of gene transcription. J Neuroinflammation 2: 8, 2005.

8. Gajate $\mathrm{C}$ and Mollinedo F: Cytoskeleton-mediated death receptor and ligand concentration in lipid rafts forms apoptosis-promoting clusters in cancer chemotherapy. J Biol Chem 280: 11641-11647, 2005.

9. Lu HF, Lai KC, Hsu SC, et al: Curcumin induces apoptosis through FAS and FADD, in caspase-3-dependent and -independent pathways in the N18 mouse-rat hybrid retina ganglion cells Oncol Rep 22: 97-104, 2009.

10. Choudhuri T, Pal S, Das T and Sa G: Curcumin selectively induces apoptosis in deregulated cyclin D1-expressed cells at G2 phase of cell cycle in a p53-dependent manner. J Biol Chem 280: 20059-20068, 2005.

11. Weir NM, Selvendiran K, Kutala VK, et al: Curcumin induces $\mathrm{G} 2 / \mathrm{M}$ arrest and apoptosis in cisplatin-resistant human ovarian cancer cells by modulating Akt and p38 MAPK. Cancer Biol Ther 6: 178-184, 2007.

12. Liu E, Wu J, Cao W, et al: Curcumin induces G2/M cell cycle arrest in a 553 -dependent manner and upregulates ING4 expression in human glioma. J Neurooncol 85: 263-270, 2007.

13. Brenner C and Kroemer G: Apoptosis. Mitochondria - the death signal integrators. Science 289: 1150-1151, 2000.

14. Blattner JR, He L and Lemasters JJ: Screening assays for the mitochondrial permeability transition using a fluorescence multiwell plate reader. Anal Biochem 295: 220-226, 2001.

15. Fleury C, Mignotte B and Vayssiere JL: Mitochondrial reactive oxygen species in cell death signaling. Biochimie 84: 131-141, 2002 .
16. Wu SH, Hang LW, Yang JS, et al: Curcumin induces apoptosis in human non-small cell lung cancer NCI-H460 cells through ER stress and caspase cascade- and mitochondria-dependent pathways. Anticancer Res 30: 2125-2133, 2010.

17. Llambi F and Green DR: Apoptosis and oncogenesis: give and take in the BCL-2 family. Curr Opin Genet Dev 21: 12-20, 2011.

18. Ip SW, Wu SY, Yu CC, et al: Induction of apoptotic death by curcumin in human tongue squamous cell carcinoma SCC-4 cells is mediated through endoplasmic reticulum stress and mitochondria-dependent pathways. Cell Biochem Funct 29: 641-650, 2011.

19. Yang CL, Ma YG, Xue YX, Liu YY, Xie H and Qiu GR: Curcumin induces small cell lung cancer NCI-H446 cell apoptosis via the reactive oxygen species-mediated mitochondrial pathway and not the cell death receptor pathway. DNA Cell Biol 31: 139-150, 2012.

20. Rao J, Xu DR, Zheng FM, et al: Curcumin reduces expression of Bcl-2, leading to apoptosis in daunorubicin-insensitive CD $34^{+}$ acute myeloid leukemia cell lines and primary sorted CD34 ${ }^{+}$ acute myeloid leukemia cells. J Transl Med 9: 71, 2011.

21. Chen QY, Lu GH, Wu YQ, et al: Curcumin induces mitochondria pathway mediated cell apoptosis in A549 lung adenocarcinoma cells. Oncol Rep 23: 1285-1292, 2010.

22. Yallapu MM, Maher DM, Sundram V, Bell MC, Jaggi M and Chauhan SC: Curcumin induces chemo/radio-sensitization in ovarian cancer cells and curcumin nanoparticles inhibit ovarian cancer cell growth. J Ovarian Res 3: 11, 2010.

23. Datta K, Babbar P, Srivastava T, Sinha S and Chattopadhyay P: p53 dependent apoptosis in glioma cell lines in response to hydrogen peroxide induced oxidative stress. Int J Biochem Cell Biol 34: 148-157, 2002.

24. Zuliani T, Denis V, Noblesse E, et al: Hydrogen peroxide-induced cell death in normal human keratinocytes is differentiation dependent. Free Radic Biol Med 38: 307-316, 2005.

25. de Wit R, Stoter G, Kaye SB, et al: Importance of bleomycin in combination chemotherapy for good-prognosis testicular nonseminoma: a randomized study of the European Organization for Research and Treatment of Cancer Genitourinary Tract Cancer Cooperative Group. J Clin Oncol 15: 1837-1843, 1997.

26. Sleijfer S: Bleomycin-induced pneumonitis. Chest 120: 617-624, 2001. 